\title{
Alberto Guerreiro Ramos e a autonomia dos estudos organizacionais críticos brasileiros: escorços de uma trajetória intelectual
}

\section{Alberto Guerreiro Ramos and the autonomy of Brazilian critical organizational studies: foreshortening of an intellectual pathway}

Gustavo Costa de Souza ${ }^{1}$

Universidade Federal de Lavras, Departamento de Administração e Economia, Programa de Pós-graduação em Administração Pública, Lavras - MG, Brasil

Antonio Lima Ornelas ${ }^{2}$

Universidade Federal Rural do Rio de Janeiro, Programa de Pós-Graduação em Gestão e Estratégia, Mestrado Profissional em Gestão e Estratégia, Seropédica - RJ, Brasil

Fundação Oswaldo Cruz, Rio de Janeiro - RJ, Brasil

\section{Resumo}

O objetivo deste ensaio teórico é tributar a Alberto Guerreiro Ramos uma homenagem às vésperas de seu centenário. Nesse sentido, nossa abordagem consiste em realçar o vigor de sua obra percorrendo as principais contribuições epistemológicas, sobretudo no que diz respeito ao problema da racionalidade, que também é discutido sob a ótica dos teóricos críticos de primeira geração e de Jürgen Habermas. O debate focaliza, principalmente, os conceitos de racionalidade substantiva e comunicativa, como contraponto à vertente instrumental. A racionalidade instrumental, em seu caráter utilitarista, impessoal e mecanicista, tornou-se hegemônica na sociedade moderna industrial. Em oposição, surgem os conceitos de substantividade e comunicatividade, que, vinculados à psique humana por meio de atributos éticos e morais, constituem, provavelmente, a melhor alternativa sustentável para a reversão do processo de unidimensionalização. Ao confrontar o que escrevem Ramos e Habermas, tanto no que se refere à solução do problema da racionalidade como no que tange aos modelos de sociedade propostos por ambos, este ensaio teórico promove a conciliação das ideias do autor brasileiro com a teoria crítica atual, demonstrando suas complementaridades e delimitações.

Palavra-chave: Racionalidade substantiva. Teoria crítica. Racionalidade comunicativa.

Artigo submetido em 31 de janeiro de 2014 e aceito para publicação em 24 de novembro de 2014.

\section{DOI: http://dx.doi.org/10.1590/1679-395115869}

${ }^{1}$ Doutor em Políticas Públicas, Estratégias e Desenvolvimento pelo Instituto de Economia da Universidade Federal do Rio de Janeiro (IE/UFRJ); Mestre em Administração Pública pela Escola Brasileira de Administração Pública e de Empresas da Fundação Getulio Vargas (EBAPE/FGV); Professor Adjunto do Departamento de Administração e Economia da Universidade Federal de Lavras - MG (DAE/UFLA) na graduação em Administração Pública e no Programa de Pós-graduação em Administração Pública (PPGAP/UFLA). Endereço: DAE/UFLA, Caixa Postal 3.037, Campus Universitário, CEP 37200-000, Lavras - MG, Brasil. E-mail: qustavo.costa@dae.ufla.br

${ }^{2}$ Especialista em Gestão de Organizações de Ciência \& Tecnologia em Saúde pela ENSP (Escola Nacional de Saúde Pública Sérgio Arouca); Discente do PPGE/MPGE/UFRRJ (Programa de Pós-Graduação em Gestão e Estratégia / Mestrado Profissional em Gestão e Estratégia / Universidade Federal Rural do Rio de Janeiro); Analista de Gestão na Fiocruz (Fundação Oswaldo Cruz). Endereço: Rua Leopoldo Bulhões, 1.480 - Pavilhão Carlos Matus - Manguinhos, CEP 21041-210, Rio de Janeiro - RJ, Brasil. Email: ornelas@fiocruz.br 


\begin{abstract}
This theoretical essay aims to pay a tribute to Alberto Guerreiro Ramos on the eve of his centenary. Thus, our approach consists in highlighting the vigor of his work by covering the main epistemological contributions, above all regarding the rationality issue, which is also discussed from the first generation critical theorists and Jürgen Habermas' viewpoint. The debate mainly focuses on the concepts of substantive and communicative rationality, as a counterpoint to the instrumental trend. Instrumental rationality, regarding its utilitarian, impersonal, and mechanistic nature, became hegemonic in the industrial modern society. In opposition, the concepts of substantiveness and communicativeness emerge, which, linked to the human psyche by means of ethical and moral features, perhaps constitute the best sustainable alternative for reversing the one-dimensionalization process. By comparing Ramos and Habermas' writings, both regarding the solution to the rationality issue and concerning the society models proposed by both of them, this theoretical essay promotes the conciliation between the Brazilian author's ideas and the current critical theory, demonstrating their complementarities and boundaries.
\end{abstract}

Keywords: Substantive rationality. Critical theory. Communicative rationality.

\title{
Introdução
}

Se vivo estivesse, Alberto Guerreiro Ramos completaria 100 anos em 2015. Contudo, ainda que atingisse todo esse tempo de vida sem mais nada produzir além do que nos deixou, a importância de sua obra já teria sido suficiente para transcender os limites temporais. Ainda há muito a estudar sobre ela antes que se esgotem as possibilidades do que tem a nos ensinar.

Guerreiro Ramos foi responsável pela renovação dos estudos sociológicos brasileiros, elevando-os a um grau de autonomia destacado no contexto da sociologia internacional. Afirmava ele que "em breve, será despertada a atenção dos estudiosos para o fato de que temos, hoje, no Brasil, uma teoria sociológica geral mais penetrante e avançada do que a norte-americana, capaz inclusive de envolvê-la e explicá-la" (GUERREIRO RAMOS, 1965, p. 135). Omitiu apenas o responsável por essa façanha, a saber, ele próprio. Em 1956, Pitirim Aleksandrovich Sorokin, renomado sociólogo russo, considerou Guerreiro Ramos um dos maiores nomes da sociologia no século XX.

Como escrevem Paes de Paula, Maranhão, Barreto et al. (2010, p. 20), a "tradição e a autonomia dos EOC [estudos organizacionais críticos] no Brasil" caracterizam-se pelas influências predominantes não só de Guerreiro Ramos, mas, também, de Maurício Tragtenberg, além de, mais recentemente, absorver as contribuições de outros "críticos brasileiros alinhados com o humanismo radical - Garcia, Serva, Tenório, Prestes Motta e Faria” (PAES DE PAULA, MARANHÃO, BARRETO et al., 2010, p. 20).

Nesse sentido, o objetivo deste artigo é tributar uma homenagem à obra desse autor que, ao longo de tanto tempo, e, às vésperas de seu centenário, tem inspirado em tantos acadêmicos, estudantes e leitores em geral o amadurecimento intelectual autônomo, voltado a um pensamento crítico essencialmente brasileiro e não subordinado às referências estrangeiras. Pretendemos, assim, percorrer e discutir as principais contribuições epistemológicas formuladas por Guerreiro Ramos para os estudos organizacionais críticos brasileiros, demonstrando, por meio de um exame breve, mas, na medida do possível, acurado, que o conjunto de sua obra constitui um sólido arcabouço conceitual capaz de impor-se criticamente a qualquer bibliografia, especialmente, como focalizaremos, àquela que compõe os estudos desenvolvidos pelos grandes nomes da Escola de Frankfurt. Acreditamos que o ponto principal será aquele onde confrontaremos os posicionamentos de Alberto Guerreiro Ramos e Jürgen Habermas, sobretudo no que concerne à visão de cada autor sobre a solução viável para o problema da racionalidade.

Com essa finalidade, estruturamos nosso texto em seis seções, além desta introdução. Primeiro, expomos um breve inventário da produção intelectual de Guerreiro Ramos com base no texto introdutório de Clóvis Brigagão, incluído no livro Introdução crítica à sociologia brasileira. Nas duas seções subsequentes, 
discorremos sobre as contribuições epistemológicas de Guerreiro Ramos para a sociologia e a Administração. A controvérsia com os teóricos críticos será tratada na quinta seção e na sexta abordamos, mais especificamente, as complementaridades e as delimitações entre as ideias de Guerreiro Ramos e Habermas. Por fim, tecemos algumas considerações finais acerca de nossa posição sobre os temas examinados.

\section{Um Breve Inventário Intelectual}

O pensamento de Alberto Guerreiro Ramos permaneceu, durante considerável fatia do nosso tempo, enclausurado nos mais desertos recônditos da intelectualidade nacional, então ávida por teorias capazes de elevar seus níveis de erudição, não obstante estivessem imbricadas em convenções que raramente a colocavam em oposição às referências basilares importadas. Nesse sentido, o viés crítico de sua obra caracterizou-se, essencialmente em sua época, não menos pelo incessante combate ao positivismo provinciano brasileiro no estudo das ciências sociais quanto pela originalidade de suas proposições, verdadeiras obras-primas de solidez teórica e metodológica (BRIGAGÃO, 1995).

No prelúdio do livro Introdução crítica à sociologia brasileira encontramos uma esquematização de seu trabalho, elaborada por Clóvis Brigagão (1995) e sustentada, como escreve o próprio autor, pelos trabalhos anteriores de Frederico Lustosa da Costa e Ramon Moreira Garcia. Brigagão (1995) propõe a divisão dos escritos de Guerreiro Ramos em quatro partes: 1) Teoria Sociológica, onde as ideias centrais concentram-se nos esforços para debelar da sociologia brasileira a absorção acrítica dos referenciais estrangeiros; 2) Organização e Ação Política, onde a atenção do autor volta-se à orientação política e social brasileira e seus conflitos entre conservadorismo e reformismo, destacando-se sua análise do processo político que antecedeu o Golpe Militar de 1964; 3) Discursos, Ensaios e Artigos, como os escritos publicados em conceituados veículos de comunicação impressa da época, como o Última Hora (final da década de 1950 e início da década de 1960) e o Jornal do Brasil (final dos anos 1970 e início dos anos 1980), falas destacadas na Assembleia Geral das Nações Unidas e no parlamento brasileiro, ensaios acadêmicos publicados pela Universidade Federal de Santa Catarina (UFSC), além de alguns artigos inéditos; e 4) Depoimentos, Testemunhos e Correspondência, grupo de material bibliográfico composto por cartas escritas por Guerreiro Ramos e trocadas com amigos e ex-alunos, principalmente durante o período em que esteve exilado nos Estados Unidos.

É importante ressalvar que, por razões que desconhecemos, essa sistematização não inclui duas obras, as quais fazemos questão de destacar, e que, como se verá adiante, terão importância determinante em nosso estudo: Administração e contexto brasileiro: esboço de uma teoria geral da Administração e, em especial, $A$ nova ciência das organizações: uma reconceituação da riqueza das nações. A fim de contribuir com o inventário montado por Brigagão (1995), optamos por incluir essas obras em um quinto grupo, que denominamos "Reflexões para uma Nova Ciência da Administração", sintetizado no Quadro 1. 
Quadro 1

Breve inventário da produção intelectual de Alberto Guerreiro Ramos

\begin{tabular}{|c|c|c|}
\hline $\begin{array}{l}\text { Fragmento } \\
\text { antológico }\end{array}$ & Produção intelectual & $\begin{array}{l}\text { Período } \\
\text { cronológico }\end{array}$ \\
\hline \multirow{2}{*}{ Teoria Sociológica } & Introdução crítica à sociologia brasileira & 1957 \\
\hline & A redução sociológica & 1965 \\
\hline \multirow{3}{*}{$\begin{array}{l}\text { Organização e Ação } \\
\text { Política }\end{array}$} & O problema nacional do Brasil & 1960 \\
\hline & A crise do poder no Brasil & 1961 \\
\hline & Mito e verdade da revolução brasileira & 1963 \\
\hline \multirow{2}{*}{$\begin{array}{l}\text { Reflexões para uma } \\
\text { Nova Ciência da } \\
\text { Administração }\end{array}$} & Administração e contexto brasileiro & 1966 \\
\hline & A nova ciência das organizações & 1981 \\
\hline \multirow{6}{*}{$\begin{array}{l}\text { Discursos, Ensaios e } \\
\text { Artigos } \\
\text { Discursos, Ensaios e } \\
\text { Artigos } \\
\text { (continuação) }\end{array}$} & $\begin{array}{l}\text { Artigos publicados em coluna semanal do jornal } \\
\text { Última Hora, do Rio de Janeiro }\end{array}$ & 1959 a 1962 \\
\hline & $\begin{array}{l}\text { Três discursos como delegado brasileiro na II Comissão } \\
\text { da XVI Assembleia Geral das Nações Unidas, em Nova } \\
\text { York }\end{array}$ & 1961 \\
\hline & Discursos parlamentares no Congresso Nacional & 1963 e 1964 \\
\hline & $\begin{array}{l}\text { Quatorze artigos publicados no Jornal do Brasil, do Rio } \\
\text { de Janeiro }\end{array}$ & 1978 a 1981 \\
\hline & $\begin{array}{l}\text { Dois ensaios acadêmicos publicados pela Universidade } \\
\text { Federal de Santa Catarina (UFSC): “O modelo } \\
\text { econômico brasileiro" e "Considerações sobre o } \\
\text { modelo alocativo do governo brasileiro" }\end{array}$ & 1980 \\
\hline & $\begin{array}{l}\text { Dois artigos inéditos: "Commerce, development, } \\
\text { protecionism, terms of trade" e "Curtição ou } \\
\text { reinvenção do Brasil" }\end{array}$ & 1982 \\
\hline $\begin{array}{l}\text { Depoimentos, } \\
\text { Testemunhos e } \\
\text { Correspondência }\end{array}$ & $\begin{array}{l}\text { Antologia de depoimentos e testemunhos de amigos, } \\
\text { intelectuais, discípulos que conviveram com Guerreiro } \\
\text { Ramos, além de farta correspondência trocada com } \\
\text { amigos e ex-alunos }\end{array}$ & 1966 a 1982 \\
\hline
\end{tabular}

Fonte: Adaptado de Brigagão (1995, p. 12-16).

De modo geral, pode-se dizer que o conjunto da obra de Guerreiro Ramos buscou sustentar um caráter crítico diante da indiscriminada adoção de modelos importados, bem como estimular nos meios intelectuais brasileiros a necessidade de tomar parte no processo de desenvolvimento do país. Além disso, produziu contribuição definitiva para as ciências sociais aplicadas ao propor um novo desenho sociológico para a Administração, cuja tessitura formou-se mais na articulação de múltiplos sistemas sociais que no modelo centrado unicamente no mercado (GUERREIRO RAMOS, 1981). 


\section{A "Sociologia em Mangas de Camisa"}

Alberto Guerreiro Ramos (1995) insistia que a existência do sociólogo brasileiro somente era justificada pela necessidade de invitar todo o seu empenho no sentido de criar condições que conduzissem o país à maturidade social e econômica. Ao mesmo tempo, defendia a ideia de que a sociologia brasileira, uma vez libertada de compromissos com a burocracia cartorial e consciente da impossibilidade contextual de admitir indiscriminadamente os padrões externos, estaria capacitada a contribuir de modo decisivo para os esforços de construção nacional. Em suas palavras:

A adoção mecânica dos métodos e processos refinados da antropologia e da sociologia europeias e norte-americanas tem levado grande parte dos profissionais brasileiros do campo dessas disciplinas a um certo descritivismo casuístico de escasso valor pragmático, isto é, pouco utilizável como contribuição para o esclarecimento dos principais problemas da sociedade brasileira (GUERREIRO RAMOS, 1995, p. 59).

Esse molde de sociologia militante foi denominado por Guerreiro Ramos (1995, p. 135) "sociologia em mangas de camisa". Em outras palavras, para Guerreiro Ramos (1995), um país somente poderia desenvolver-se à medida que fosse capaz de compreender a dinâmica do contexto socioeconômico peculiar ao seu momento histórico, abominando a transferência acrítica de experiências forasteiras. Nesse processo, os sociólogos seriam os peritos, por excelência, mais credenciados a levar a termo esse novo tipo de visão.

\section{A refutação do falso idealismo brasileiro}

Um dos primeiros rompimentos epistemológicos estabelecidos por Guerreiro Ramos (1995) diz respeito ao que Oliveira Viana, um dos poucos intelectuais nacionais a quem realmente respeitava (outros são Sylvio Romero, Pontes de Miranda, Euclides da Cunha, Alberto Torres, Emílio Willems, Fernando de Azevedo, Gilberto Freyre e Carneiro Leão), denominou "idealismo utópico brasileiro". Segundo Guerreiro Ramos (1995), a teoria de Viana acerca dos históricos "idealistas nacionais" não se consubstanciava inteiramente verdadeira, à medida que sua atitude concreta, de modo geral, descolava-se de seus discursos, normalmente convertidos em mera verborragia copiada dos enfoques estrangeiros mais influentes na época. Nesse sentido, Guerreiro Ramos (1995) pautou alguns momentos históricos relevantes para os quais emitiu uma análise, admitida por ele mesmo como superficial, contudo, sem ser, por isso, imprecisa.

De acordo com Guerreiro Ramos (1995), esse divórcio entre manifestação locucionária e prática cotidiana, revela-se muito profundamente no grupo republicano de 1870, cujos integrantes eram pinçados, em sua grande maioria, dos profissionais liberais de classe média e dos primeiros oligarcas latifundiários, que, em última análise, estavam atentos apenas aos próprios interesses. Acrescenta o autor que não mais pseudoidealista era o positivismo brasileiro, seguidor de Augusto Comte, que, às portas da proclamação da República, desejava implantar no Brasil o modelo de sociedade europeu. Embora admita o caráter utópico dos positivistas nacionais, Guerreiro Ramos (1995, p. 85) ressalta que o "programa de medidas que preconizavam para o problema brasileiro, em muitos aspectos, apresentava cunho prático, do ponto de vista da classe social a que majoritariamente pertenciam".

Na esteira desse processo histórico, escreve Guerreiro Ramos (1995), inicialmente com base em trabalhos ulteriores de Sylvio Romero, já no período republicano, que os marcos revolucionários do Brasil, como os movimentos de 1922 e 1924, a Coluna Prestes e a chegada ao poder de Getúlio Vargas, em 1930, consistem, essencialmente, no confronto entre os interesses opostos da classe média e da burguesia latifundiária e mercantil brasileira. Em outras palavras, esse conflito político da primeira metade do século XX de forma alguma criou bases para a "formulação de uma ideologia orgânica da realidade brasileira" (GUERREIRO RAMOS, 1995, p. 98). 


\section{A redução sociológica}

Um dos princípios norteadores da obra de Guerreiro Ramos define-se pela abominação irrestrita da “assimilação literal e passiva dos produtos científicos importados" (GUERREIRO RAMOS, 1965, p. 80). Dessa forma, o autor elaborou um cuidadoso procedimento metodológico tendo por objetivo promover a capacidade sistemática de absorção crítica de tais produtos. Esse método foi denominado por Guerreiro Ramos (1965, p. 81-82) redução sociológica, conceituada nos seguintes termos:

No domínio restrito da sociologia, a redução é uma atitude metódica que tem por fim descobrir os pressupostos referenciais, de natureza histórica, dos objetos e fatos da realidade social. A redução sociológica, porém, é ditada não somente pelo imperativo de conhecer, mas também pela necessidade social de uma comunidade que, na realização de seu projeto de existência histórica, tem de servir-se da experiência de outras comunidades.

Em outras palavras, a redução sociológica consiste em esforço exaustivo a fim de excluir da análise de determinada realidade social os elementos que possam vir a obscurecer a percepção dos significados que a compõem. Guerreiro Ramos (1965) descreve a redução sociológica como uma metodologia detalhista, entremeada por valores e pressupostos, imbricada especialmente nos contextos e que, por isso, nunca considerará possível a existência de realidades sociais iguais. Além disso, ela atrai para si a necessidade de ser sustentada por um processo social coletivo que vise a submeter a prática da adoção de modelos estrangeiros a "apurados critérios de seletividade" (GUERREIRO RAMOS, 1965, p. 84).

Do ponto de vista filosófico, o conceito de redução sociológica apoia-se na abordagem heideggeriana, segundo a qual o sentido dos objetos só podem ser compreendidos em função de sua relação com o mundo (GUERREIRO RAMOS, 1965). Este, ao contrário do que preconizava a filosofia tradicional, não pode ser entendido como um "dado externo ao homem" (GUERREIRO RAMOS, 1965, p. 99), sendo, ao contrário, a referência concreta que possibilita a percepção da realidade. Seguindo essa vertente, referências diferentes implicam realidades diferentes. Explicita-se aí o caráter ingênuo da transposição acrítica de produtos culturais, acreditando, equivocadamente, que estes são capazes de provocar os mesmos efeitos em todos os contextos (GUERREIRO RAMOS, 1965).

Assim como Martin Heidegger constitui a fundamental influência filosófica para a consolidação do conceito de redução sociológica, coube principalmente a Karl Mannheim ceder a Guerreiro Ramos os substratos sociológicos que auxiliaram sua sustentação. Segundo Mannheim (1968, p. 124), as concepções sociológicas devem, ao máximo, impedir a separação entre pensamento do "mundo da realidade". Ainda segundo o autor, quanto mais estiver próximo da realidade, mais o pensamento contribuirá para sua efetiva compreensão. Assim, da mesma forma que pensamento e realidade devem unir-se, conclui Guerreiro Ramos (1965) que objeto e referencial, igualmente, devem se vincular e, apenas dessa forma, produzirão adequada significação. Confirma-se, então, o juízo de que cada significado corresponde a determinado contexto e que a alteração de um ou de outro, sem o cuidadoso exame, conduz a uma inviabilidade teórica.

Ainda é possível acrescentar que a redução sociológica, seguindo a coerência das ideias expostas até aqui, "só admite a universalidade da ciência tão somente no domínio dos enunciados gerais" (GUERREIRO RAMOS, 1965, p. 131). Em outras palavras, conceitos gerais não podem ser aplicados indiscriminadamente em contextos específicos, sendo que somente de forma subsidiária poderá um conceito ser assimilado fora de seu respectivo contexto original.

É importante ressalvar que a noção de redução sociológica impõe significativos reflexos no âmbito dos estudos organizacionais. É por isso que, não sem propriedade, Faria (2009, p. 443) chama a atenção, inclusive, para a atualidade do conceito: "A preocupação de Guerreiro Ramos com a importação de teorias, formulada no início dos anos 1950 e, posteriormente, nos anos 1980, com a transposição descuidada de conceitos, é hoje ainda prática usual nos estudos organizacionais". 


\section{Teoria $\mathbf{N}$ e teoria $\mathbf{P}$}

Contudo, parece-nos que, até ordenar a ideia de redução sociológica, Guerreiro Ramos (1965) ainda admitia categorizar como subdesenvolvidas as regiões do mundo que economicamente posicionavam-se em patamares inferiores quando tomadas em relação a um referencial universal de desenvolvimento, normalmente o europeu e o norte-americano. Esse aspecto, entretanto, não resiste à atenta leitura de textos posteriores que revelam sua preocupação em inspirar uma concepção de desenvolvimento associada à modernização que fosse diversa das classificações compartimentalizadas que dividiam as nações do planeta em primeiro, segundo e terceiro mundo.

Nesse sentido, Guerreiro Ramos (2009) também se dedicou à espinhosa tarefa de examinar cuidadosamente o conceito de modernização, empreitada que, segundo ele, embora não tenha sido negligenciada, não foi suficientemente esclarecida por outros estudiosos do tema. Dessa forma, Guerreiro Ramos (2009) introduz em sua obra mais uma importante contribuição epistemológica, ao situar as diferentes noções de modernização em um continuum cujos dois polos designou como $\mathrm{N}$ e P.

Segundo o autor, os adeptos da teoria $\mathrm{N}$ acreditam existir um referencial universal de modernização, normalmente associado aos Estados Unidos e à Europa Ocidental. Lançando mão desse referencial para graduar as sociedades, esses estudiosos tendem a reproduzir classificações dicotômicas como "desenvolvimento" e "subdesenvolvimento" (GUERREIRO RAMOS, 2009, p. 43). Já aqueles que se alinham com a teoria P não acreditam que a modernização deve necessariamente orientar-se por um único modelo preestabelecido, considerando-a um processo peculiar de cada nação e que só tem a perder com a imposição de modelos distantes de suas realidades.

$\mathrm{Na}$ essência do debate entre essas duas teorias encontra-se a noção de "possibilidade" (GUERREIRO RAMOS, 2009, p. 45), a qual é compreendida de forma antagônica em cada uma delas. Para a teoria N, em dado momento histórico, aquilo que aconteceu é exatamente o que tinha de ter ocorrido. Dizendo de outra forma, só existe um nexo causal possível, de acordo com o qual os fatos se articulam para resultar em determinado acontecimento.

Ao contrário, de acordo com a teoria $\mathrm{P}$, o acontecimento resultante de uma conexão histórica de fatos foi apenas uma entre várias possibilidades cabíveis sobre o que poderia ter ocorrido. Sobre isso, Guerreiro Ramos (2009) destaca o pensamento ucrônico de Charles Renouvier cuja essência está estreitamente relacionada ao conceito de teoria P. De acordo com esse autor, a "ucronia é uma utopia do passado, uma exposição de acontecimentos que não tiveram lugar" (GUERREIRO RAMOS, 2009, p. 47). Em outras palavras, admite-se que teria sido possível, em um mesmo acontecimento histórico, uma diferente composição dos fatos que conduziria a uma realidade também diferente.

Cabe destacar a importância das teorias $\mathrm{N}$ e $\mathrm{P}$ para os estudos organizacionais brasileiros, à medida que, por exemplo, forneceram as bases metodológicas para o esforço empreendido por Zwick, Teixeira, Pereira et al. (2012) no sentido de promover uma análise acerca do peculiar arranjo da administração pública brasileira. Segundo os autores: "propõe-se que a composição encontrada no Brasil, em especial das abordagens burocrática, gerencialista e dos indícios de gestão social formam o que denominamos 'administração pública tupiniquim" (ZWICK, TEIXEIRA, PEREIRA et al., 2012, p. 298). O Quadro 2 apresenta os sete pares de suposições que definem com clareza a proposição de Guerreiro Ramos (2009) para o modelo da possibilidade, segundo as teorias $\mathrm{N}$ e $\mathrm{P}$. 
Quadro 2

Modelo da possibilidade segundo as teorias $\mathbf{N}$ e $\mathbf{P}$

\begin{tabular}{|c|c|}
\hline Teoria N & Teoria P \\
\hline $\begin{array}{l}\text { Tudo o que aconteceu é a única coisa que poderia ter } \\
\text { acontecido. }\end{array}$ & $\begin{array}{l}\text { Tudo o que aconteceu é uma entre } \\
\text { as muitas possibilidades objetivas } \\
\text { que poderiam ter acontecido. }\end{array}$ \\
\hline $\begin{array}{l}\text { O curso dos acontecimentos resulta da ação recíproca } \\
\text { de causas absolutamente necessárias. Uma mente } \\
\text { onisciente, que conhece todas essas causas } \\
\text { necessárias, poderia prever, com absoluta certeza, o } \\
\text { que terá de acontecer a curto e longo prazo. Presume- } \\
\text { se como possível o conhecimento sinóptico do } \\
\text { processo social. }\end{array}$ & $\begin{array}{l}\text { Nenhum curso de acontecimentos pode ser } \\
\text { considerado resultante da ação recíproca de causas } \\
\text { absolutamente necessárias. O curso dos } \\
\text { acontecimentos resulta continuamente do jogo entre } \\
\text { fatores objetivos e opções humanas. Assim, é possível } \\
\text { fazer previsões, mas apenas com graus variáveis de } \\
\text { certeza, dependendo sempre das circunstâncias } \\
\text { concretas. Jamais poder-se-ia chegar a um } \\
\text { conhecimento sinóptico do processo social. }\end{array}$ \\
\hline $\begin{array}{l}\text { O que faz o homem pensar em possibilidades é sua } \\
\text { ignorância ou seu conhecimento incompleto do curso } \\
\text { dos acontecimentos necessários. Existem apenas } \\
\text { possibilidades epistêmicas ou lógicas. }\end{array}$ & $\begin{array}{l}\text { As possibilidades podem ser reais e empiricamente } \\
\text { demonstradas. A possibilidade objetiva opõe-se à } \\
\text { possibilidade abstrata, eis que se relaciona } \\
\text { necessariamente com uma situação dada; esta } \\
\text { possibilidade pode realizar-se. }\end{array}$ \\
\hline $\begin{array}{l}\text { Existe um processo normal e unilinear de evolução, } \\
\text { um caminho ótimo e único a ser palmilhado rumo ao } \\
\text { futuro. Se observarmos os pré-requisitos, podemos } \\
\text { evitar descaminhos e colapsos. }\end{array}$ & $\begin{array}{l}\text { Não existe processo normal unilinear. A história } \\
\text { sempre nos apresenta um horizonte aberto a } \\
\text { possibilidades múltiplas. Em qualquer momento } \\
\text { podem ocorrer eventos inesperados, conduzindo a } \\
\text { sociedade a um novo estágio diferente da imagem } \\
\text { convencional de seu futuro. }\end{array}$ \\
\hline $\begin{array}{l}\text { No que tange ao presente, a tarefa da ciência social é } \\
\text { mostrar o que, em última análise, irá necessariamente } \\
\text { acontecer e estabelecer os pré-requisitos ou requisitos } \\
\text { para sua realização com base no que aconteceu } \\
\text { anteriormente. }\end{array}$ & $\begin{array}{l}\text { No que concerne ao presente, a tarefa da ciência } \\
\text { social é descobrir o horizonte de suas possibilidades, a } \\
\text { fim de contribuir para a participação humana na } \\
\text { construção e para a transformação consciente das } \\
\text { sociedades contemporâneas. }\end{array}$ \\
\hline $\begin{array}{l}\text { É pernicioso ao cientista social ser protagonista no } \\
\text { processo social. Ele deve ser um espectador, um } \\
\text { observador afastado da arena dos interesses, a fim de } \\
\text { ser capaz de ver, sem ideias preconcebidas, a } \\
\text { orientação ao rumo transcendente do processo. }\end{array}$ & $\begin{array}{l}\text { Sem ser protagonista no processo social não se pode } \\
\text { ser integralmente um cientista social. A ideia de um } \\
\text { pensar separado da prática é uma contradição de } \\
\text { termos. Não há pensar sem um rudimento de prática, } \\
\text { nem há prática sem um rudimento de teoria. }\end{array}$ \\
\hline
\end{tabular}


Na história contemporânea, devemos distinguir sociedades em desenvolvimento. As primeiras, como sociedades paradigmáticas, exibem às subdesenvolvidas a imagem do futuro destas. Deve-se elaborar indicadores de desenvolvimento ou modernização, para que os agentes incumbidos do aprimoramento das condições nas sociedades em desenvolvimento possam orientar-se quanto à melhor maneira de alcançar a modernização ou o desenvolvimento.
No momento atual da história, a dicotomia entre sociedades desenvolvidas é teoricamente desnorteadora. Na realidade, a categoria cardinal das ciências sociais é o mundo, que hoje possui as características de um sistema. Sob a ótica desse sistema, todas as sociedades estão em desenvolvimento. Todas elas são, em diferentes graus, ao mesmo tempo atrasadas e modernas. Só podem existir indicadores ad hoc de modernização, e sua natureza e relação só fazem sentido quando estão associadas a possibilidades de desenvolvimento ou modernização de cada sociedade.

Fonte: Guerreiro Ramos (2009, p. 54-55).

Cont. Quadro 2

Podemos, enfim, concluir que a sociologia de Guerreiro Ramos destaca-se, fundamentalmente, pelo pioneirismo epistemológico, reconhecido não só nacional como internacionalmente, tendo como atributos indeléveis a autonomia de seus construtos intelectuais, a sofisticação metodológica e a coerência analítica. Sua envergadura intelectual seria ainda muito bem aplicada nos estudos sobre as teorias organizacionais, como veremos adiante.

\section{Por uma Nova Ciência da Administração}

O esforço dispendido por Guerreiro Ramos no campo da Administração "supõe a validade de um projeto de construir uma sociologia especial" (GUERREIRO RAMOS, 1983, p. 28), tendo como base epistemológica o conceito de redução sociológica, elaborado pelo próprio autor. Com esse propósito, Guerreiro Ramos publicou duas obras: Administração e estratégia de desenvolvimento, em 1966 (republicada em 1983 com o título de Administração e contexto brasileiro) e A nova ciência das organizações, em 1981. O hiato de quinze anos entre um livro e outro não foi em vão. O que Guerreiro Ramos considerou embrionário em 1966 transformou-se em uma de suas construções intelectuais mais primorosas no final do século XX.

\section{Revirando a ciência administrativa}

Segundo Guerreiro Ramos (1983), o amadurecimento da teoria administrativa passa, necessariamente pela aquisição da totalidade. Dizendo de outra maneira, tanto interna como externamente, os elementos sociais que compõem um fato administrativo devem estabelecer elos contínuos e não devem ser entendidos de modo desarticulado. Nas palavras de Guerreiro Ramos (1983, p. 29), o fato administrativo é definido como:

Complexo de elementos e de suas relações entre si, resultante e condicionante da ação de diferentes pessoas, escalonadas em diferentes níveis de decisão, no desempenho de funções que limitam e orientam atividades humanas associadas, tendo em vista objetivos sistematicamente estabelecidos.

Esse axioma revela a repulsa do autor pelas teorias que buscam dividir o conhecimento em fragmentos que tratam as questões da ciência de forma isolacionista. Especialmente em relação às ciências sociais, Guerreiro Ramos (1983) almejou, de fato, promover uma mudança de paradigma capaz de dar impulso a um novo modo de compreensão, notadamente mais global. Concedeu centralidade à Administração, à medida que 
considerava as organizações, em seus aspectos intrínsecos e extrínsecos, cada vez mais imbricadas nos fatores particulares e universais da sociedade.

Apõe Guerreiro Ramos (1983, p. 92), ainda, que todo fenômeno que envolva a Administração não deve conferir caráter central à técnica administrativa em detrimento de "variáveis histórico-sociais". Uma vez que o processo, a princípio inevitável, de industrialização tem atribuído papel decisivo à tecnologia, a tendência de uniformização universal da "arte de administrar", converge para um modelo social onde a "psicologia e a ética" tecnológicas e organizacionais impõem-se sobre toda a sociedade (GUERREIRO RAMOS, 1983, p. 93).

É Guerreiro Ramos (1983) quem também insere com mais contundência a obra de Max Weber nos estudos brasileiros sobre Administração. Em 2006, a Revista do Serviço Público republicou um ensaio teórico seu, escrito em 1946, intitulado A sociologia de Max Weber. Na ocasião, Guerreiro Ramos (1946, p. 267-268), essencialmente baseado em obras como Economia e sociedade, História econômica geral e A ética protestante e o espírito do capitalismo, deixa transparecer sua admiração pelo autor alemão ao escrever:

O responsável por esta seção [Guerreiro Ramos] não tem a veleidade de pretender fazer uma crítica desta obra, cuja influência capital na formação das ciências sociais é hoje universalmente reconhecida. Terá atingido o seu objetivo se conseguir, nas linhas que se seguem, expor com clareza alguns temas fundamentais da sociologia de Max Weber [...].

Guerreiro Ramos (1946, p. 269) destaca nesse estudo o "tipo ideal" como "categoria central" da metodologia weberiana. Segundo o autor, fundamental para a compreensão dessa tipologia é a "admissão de que a ciência não é uma cópia da realidade, de que nosso conhecimento da realidade é, portanto, necessariamente limitado e imperfeito" (GUERREIRO RAMOS, 1946, p. 269). Em outras palavras, os tipos ideais são, antes, referências extremas em relação às quais tais imperfeições podem ser mais bem captadas.

A lúcida interpretação de Guerreiro Ramos (1946) a respeito de Weber revela-se ainda mais consistente na apreciação que faz o autor acerca do conceito de racionalização. Segundo Guerreiro Ramos (1946, p. 272), "a racionalização é a transformação da comunidade em sociedade, isto é, da organização social fundada na santidade da tradição e nos sentimentos humanos em uma organização social fundada na calculabilidade dos atos e na objetividade racional". Ou seja, o que conhecemos como sociedade originou-se por meio da racionalização, no exato recorte histórico em que ocorreu a transição do tradicionalismo para a secularização.

As ideias weberianas são utilizadas por Guerreiro Ramos para defender a utilidade da burocracia na estratégia de desenvolvimento nacional. Em consonância com o pensamento de Max Weber, justifica-se plenamente a afirmação de Guerreiro Ramos (1983) de que os sistemas sociais burocráticos são mais avançados que os não burocráticos. Ambos os autores comungam a ideia de que a racionalidade aplicada às estruturas organizacionais contribui para a moderação de "impulsos irracionais" (WEBER, 2001, p. 26). Além disso, Guerreiro Ramos (1983), tanto quanto Weber, considera que a burocracia em si não é boa nem má, consistindo tão somente no reflexo social de determinado contexto histórico.

Entretanto, Guerreiro Ramos (1983) não nega que a burocracia está intimamente relacionada às estruturas de poder. Essa relação, porém configura-se de modo difuso, a burocracia "como agrupamento social jamais se torna sujeito do poder político" (GUERREIRO RAMOS, 1983, p. 239). Em outras palavras, segundo Maurício Tragtenberg (2006), a burocracia torna-se poderosa enquanto ideologia, ou seja, enquanto arcabouço conceitual capaz de contagiar uma sociedade de maneira individual e coletiva.

\section{A racionalidade substantiva}

A discussão sobre burocracia normalmente traz à tona o debate sobre racionalidade. Guerreiro Ramos (1981), criticando a razão moderna, denunciou a deturpação do conceito de razão, manifestada por sua compatibilização ideológica, no sentido de torná-lo palatável ao modus operandi utilitarista e instrumental de 
uma sociedade centrada no mercado. O autor acusa a sociedade moderna de deformar os significados de conceitos e palavras, a fim de garantir sua própria sustentação:

Uma vez que a palavra razão dificilmente poderia ser posta de lado, por força de seu caráter central na vida humana, a sociedade moderna tornou-a compatível com sua estrutura normativa. Assim, na moderna sociedade centrada no mercado, a linguagem distorcida tornou-se normal, e uma das formas de criticar essa sociedade consiste na descrição de sua astúcia na utilização inapropriada do vocabulário que prevalecia antes de seu aparecimento (GUERREIRO RAMOS, 1981, p. 3).

Em seu sentido original, é a razão "que habilita o indivíduo a distinguir entre o bem e o mal, entre o conhecimento falso e o verdadeiro e, assim, a ordenar sua vida pessoal e social" (GUERREIRO RAMOS, 1981, p. 2-3). Em outras palavras, a razão é uma só, com o atributo, tanto de distinguir o falso do verdadeiro como de exercer o cálculo. Esse mesmo sentido deveria ser recuperado de seu aspecto indissociável da psique humana e não apenas de um conjunto de requisitos instrumentais (GUERREIRO RAMOS, 1981). Eis um ponto que será constantemente repisado pelo autor: a hegemonia da racionalidade instrumental solapa uma verdadeira e saudável ordem social. A compreensão unidimensional de razão transmutada nessa espécie de racionalidade associada a critérios utilitaristas de produtividade, não passa, fundamentalmente, de um engodo, de um logro, perpetuado, inclusive com a anuência das ciências sociais, em particular das ciências organizacionais.

Se nos remetermos à gênese da ideia de racionalidade, veremos que, segundo Aristóteles (2001), a alma humana convive hipostaticamente com princípios racionais e irracionais. Nesse sentido, de acordo com o filósofo grego, a racionalidade humana desenvolve-se a fim de conciliar a sabedoria prática com a razão intuitiva, atribuindo esse estágio à plenitude da razão:

Todas as disposições que estivemos examinando convergem para o mesmo ponto; de fato, quando falamos de discernimento, de inteligência, de sabedoria prática e de razão intuitiva, atribuímos às mesmas pessoas a posse do discernimento, e dizemos que elas atingiram a idade da razão (ARISTÓTELES, 2001, p._131).

A estrutura do pensamento aristotélico, segundo a qual em todas as coisas a natureza da virtude consubstancia-se no meio-termo ou mediania entre dois vícios (ARISTÓTELES, 2001), talvez possa nos levar à conclusão, por analogia, de que a supremacia da sabedoria (ou racionalidade) prática sobre a razão intuitiva, e também o inverso, empurraria a racionalidade humana para os limites da irracionalidade. Ou, como escreve Guerreiro Ramos (1981, p. 30) acerca do que diz Aristóteles: "No momento que o ser humano é reduzido a uma criatura que calcula, é para ele impossível distinguir entre vício e virtude”.

Voltando às ideias de Max Weber, é importante apontar, como destaca Guerreiro Ramos (1981, p. 25), a separação realizada, pelo sociólogo alemão, do que ele denominava "Zweckrationalität (racionalidade formal) e Wertrationalität (racionalidade substantiva)". Weber dedicou-se a construir uma teoria voltada ao estudo da racionalidade formal enquanto Guerreiro Ramos (1981, p. 25), em suas próprias palavras, detevese na "ideia de que uma teoria substantiva poderia ser formulada com base naquilo que Weber não disse".

Em sua obra, além de procurar definir o que propriamente seria a racionalidade formal, Weber (2001) atevese, também, à tarefa de estruturar um pensamento capaz de explicar historicamente como esse modelo de princípio racional tornou-se predominante na sociedade moderna. Segundo Weber (2001, p. 32), a técnica e o direito são aspectos fundamentais na sustentação do racionalismo econômico, mas, para que este atingisse o posto de ideologia hegemônica, haveria a necessidade "do homem em adotar certos tipos de conduta racional prática”. Essa racionalidade prática, muito diferente do que dizia Aristóteles, implica uma exacerbada disposição de ganhos financeiros como finalidade da vida: 
A aquisição econômica não mais está subordinada ao homem como um meio para a satisfação de suas necessidades materiais. Essa inversão daquilo que chamamos de relação natural, tão irracional de um ponto de vista ingênuo, é evidentemente um princípio-guia do capitalismo [...] A economia capitalista moderna é um imenso cosmos no qual o indivíduo nasce, e que se lhe afigura, ao menos como indivíduo, como uma ordem de coisas inalterável, na qual ele tem de viver. Ela força o indivíduo, na medida em que ele esteja envolvido no sistema de relações de mercado, a se conformar às regras de comportamento capitalistas (WEBER, 2001, p. 51-52).

Entretanto, para entender a constituição da vida segundo as regras da sociedade centrada no mercado, é preciso compreender como se originou esse ethos particular, contrário ao sentimento ético de outras épocas e capaz de justificar a adaptação humana a um sistema controlado por relações de dominação como se fosse algo absolutamente "natural". Nesse sentido, afirma Weber (2001) que essa distorção ética, direcionada à obtenção do lucro como finalidade, surge na ideia de "vocação" como recomendado pela doutrina calvinista.

Ainda que o calvinismo, enquanto corrente doutrinária do protestantismo, não se propunha deliberadamente, como acentua Weber (2001), a recriar as condutas éticas como forma de sustentar ideologicamente o "espírito do capitalismo", sua concepção de "vocação" contribuiu, significativamente, para sua consolidação. É sobretudo na doutrina da predestinação, "o dogma mais característico do Calvinismo" (WEBER, 2001, p. 83), que se assenta o princípio, segundo o qual, os sinais da graça de Deus manifestavam-se na vida do fiel, em última análise, pela quantidade de bens materiais acumulados. Dessa forma, distinções comumente associadas ao puritanismo protestante, como o ascetismo, o trabalho duro e intenso, a racionalização do tempo são apontados como o caminho mais curto para a "salvação". O pensador alemão acrescenta:

À medida que se foi disseminando a influência da concepção de vida puritana - e isso é, naturalmente, muito mais importante que um simples encorajamento ao acúmulo -, ela favoreceu o desenvolvimento da vida econômica racional da burguesia; foi a mais importante e, acima de tudo, a única influência consistente para o desenvolvimento desse tipo de vida. Foi, diríamos, o berço do homem econômico moderno (WEBER, 2001, p. 135, grifo nosso).

Portanto, segundo os argumentos weberianos, fica presumivelmente claro que as origens da racionalidade formal estão intimamente imbricadas nos traços éticos forjados pelo ascetismo cristão. Entretanto, como Weber (2001, p. 140) propriamente acrescenta, o "capitalismo vitorioso, uma vez que repousa em fundamentos mecânicos, não mais precisa de seu suporte". A busca pela riqueza material não parece mais desejar estabelecer qualquer vínculo espiritual seja lá com qual doutrina for. Ao contrário, como diz Karl Polanyi (2000, p. 58), criou-se "um novo credo totalmente materialista que acreditava que todos os problemas poderiam ser resolvidos por uma quantidade ilimitada de bens materiais". Embora Polanyi talvez por sua orientação cristã calvinista -, não tenha se dedicado exatamente a encontrar a semente do ethos capitalista, como fez Weber, ele soube expressar com clareza, em uma frase, a inflexão que transferiu tudo o que era exclusivo da economia para o cerne da sociedade: "Em vez de a economia estar embutida nas relações sociais, são as relações sociais que estão embutidas no sistema econômico" (POLANYI, 2000, p. 77).

Entretanto, segundo Guerreiro Ramos (1981), já não é possível admitir, como na época de Weber e Polanyi, a ausência absoluta de uma racionalidade substantiva como contraponto à racionalidade formal, sob pena de incorrer em incoerência intelectual. Nesse sentido, concorda Maurício Serva (1997, p. 30), que menciona, inclusive, o próprio Guerreiro Ramos:

De Polanyi a Godelier, desembocando em Guerreiro Ramos, um substancial conjunto de pesquisadores $\mathrm{v}[\mathrm{e}] \mathrm{m}$ demonstrando que a sociedade centrada no mercado é apenas uma forma recente de ordenação da vida humana associada. Assim sendo, outras formas de 
ordenação social e de produção podem ser encontradas atualmente, exigindo para a sua análise outros instrumentos de interpretação e também referenciais alternativos à lógica utilitarista.

Escrevendo de outra forma, isso significa expandir as possibilidades de compreensão para incluir elementos até então imersos nas obras de diversos autores, que, embora jamais tenham se referido explicitamente a um conceito de razão substantiva, fornecem subsídios indiscutíveis para seu entendimento (GUERREIRO RAMOS, 1981).

Dessa forma, Guerreiro Ramos (1981) sustenta, ao citar Aristóteles, que a verdadeira razão é aquela capaz de promover a transição do homem de um ser "puramente natural e socialmente determinado" para um "ator político" (GUERREIRO RAMOS, 1981, p. 28). Acrescenta o autor que, "no domínio político, o homem é destinado a agir por si mesmo como um portador da razão no sentido substantivo" (GUERREIRO RAMOS, 1981, p. 30). Assim, o autor abomina veementemente a ideia, com frequência aceita, de que a conduta moral do homem é totalmente moldada pela sociedade na qual está inserido. Em outras palavras, o autor repudia categoricamente as teses de que os indivíduos transformaram-se em seres exclusivamente sociomórficos. Não obstante, considera que a racionalidade substantiva está na natureza humana e constitui-se, justamente, na única saída para reverter a hegemonia da racionalidade instrumental e sua socialização histórica (GUERREIRO RAMOS, 1981, p. 46):

A história é um simpósio permanente, inteligível, no qual todas as gerações se compreendem umas às outras. Mas não é a própria história que nos permite sermos inteligíveis e inteligentes. Antes, é a razão, em sentido substantivo, que capacita os seres humanos a compreenderem as variedades históricas da condição humana.

Dizendo de outra maneira, é a razão, em sua essência substantiva que, uma vez revivificada, deve subordinar a história e não o inverso. Urge, segundo Guerreiro Ramos (1981), a necessidade de que as ciências sociais, incluindo-se aí e talvez, principalmente, as aplicadas, abandonem a lógica formal e recuperem sua capacidade substantiva, a fim de influir diretamente na regulação do processo econômico. Ainda segundo o autor, tal influência precisará promover "uma ruptura histórica [...] através de uma mudança no íntimo das pessoas, em sua orientação relativamente à realidade e nos critérios de percepção e definição de suas necessidades e desejos" (GUERREIRO RAMOS, 1981, p. 42). Não se trata, porém, de uma missão fácil. Não há antecedentes históricos que apontem a existência de um tempo como este no qual o processo de socialização unidimensionalizado encontra-se tão sedimentado a ponto de subordinar tão "naturalmente" o comportamento humano à ação livre e sem controle da lógica de mercado.

\section{O paradigma paraeconômico e o arcabouço da nova ciência}

Como mencionado, Alberto Guerreiro Ramos compreendia as organizações como o instituto social cuja influência é notadamente decisiva na propagação do logos utilitarista. Nesse sentido, é a partir da reformulação da teoria organizacional, com a substituição do paradigma instrumental pelo protagonismo da racionalidade substantiva, que se sustenta a "nova ciência das organizações" (GUERREIRO RAMOS, 1981, p. 118).

Normalmente, a literatura organizacional consagrada recomenda que a organização deve ser capaz de adaptar-se aos estímulos exteriores. De acordo com a nova ciência das organizações, essa premissa é falsa e, não obstante, verifica-se justamente o contrário. No contexto da sociedade centrada no mercado, todas as relações sociais, desde as processadas no mais modesto núcleo familiar até aquelas praticadas nas redes mais complexas, são determinadas de modo utilitarista, emanadas, justamente, das organizações formais (GUERREIRO RAMOS, 1981). 
Dessa forma, todas as dimensões da vida humana são afetadas, mas é provavelmente no "trabalho" que seu reflexo se repara de maneira mais contundente. Trabalho e ocupação são diferentes à medida que o termo "trabalho" associou-se à realização de um conjunto de atividades mensuráveis única e exclusivamente em bases quantitativas e postas a serviço do sistema de mercado. Normalmente, é entendido como algo sacrificante e penoso. Já a "ocupação" agrega-se à ideia de uma prática que conduz o indivíduo à "atualização pessoal". Esta acrescenta a ele valores existenciais, deve ser realizada de acordo com seu desejo pessoal e é, via de regra, gratificante. A atualização pessoal, somente de forma incidental, ocorre nos domínios da vertente estritamente econômica (GUERREIRO RAMOS, 1981).

Assim, a organização, concebida pela nova ciência propugnada por Guerreiro Ramos (1981), precisa assumir as seguintes características: 1) seus limites devem se restringir ao âmbito estritamente econômico como um enclave entre tantos outros, nunca como abordagem predominante; 2) o comportamento administrativo, da mesma forma, precisa ficar restrito ao domínio da administração sem, contudo, inibir as demais potencialidades humanas; 3 ) as organizações econômicas compõem um sistema social como vários outros com os quais deve se articular e não sobrepujar; 4) de forma alguma as organizações devem favorecer compulsões desnecessárias, ao contrário, devem ter por objetivo o aumento da satisfação pessoal de seus integrantes; e 5) os desenhos organizacionais devem adequar-se aos interesses humanos da boa sociedade ou da possibilidade de atualização pessoal, e não o contrário (GUERREIRO RAMOS, 1981).

A aplicação desse modelo de organização requer, necessariamente, um novo modelo de sociedade que abandone o caráter unidimensional e reconheça como legítima a multidimensionalidade humana, ou seja, a sociedade multicêntrica; Guerreiro Ramos (1981, p. 141) denominou esse novo modelo paradigma paraeconômico:

Primeiro e acima de tudo, o padrão paraeconômico parte do pressuposto de que o mercado constitui um enclave dentro de uma realidade social multicêntrica, onde há descontinuidades de diversos tipos, múltiplos critérios substantivos de vida pessoal e uma variedade de padrões de relações interpessoais. Segundo, nesse espaço social, só incidentalmente o indivíduo é um maximizador da utilidade e seu esforço básico é no sentido da ordenação de sua existência de acordo com as próprias necessidades de atualização pessoal. Terceiro, nesse espaço social, o indivíduo não é forçado a conformar-se inteiramente ao sistema de valores de mercado.

Enquanto a ausência de racionalidade substantiva constrói a base do diagnóstico feito por Guerreiro Ramos (1981) acerca da teoria convencional das organizações, a introdução do paradigma paraeconômico ocupa a centralidade de sua proposta para a nova ciência das organizações. Nele, a economia é apenas uma das possibilidades para a arquitetura de sistemas sociais. O multicentrismo mencionado por Guerreiro Ramos (1981) revela-se na articulação da economia com outros enclaves tais como a isonomia e a fenonomia, onde nenhum deles deve predominar. A isonomia fundamenta-se em possíveis formatos de ambientes sociais igualitários enquanto que a fenonomia revela-se na conservação da escolha individual ou de poucos seres humanos com o mínimo de imposições funcionais formais. Nesse contexto, os extremos paradigmáticos são compostos pela anomia e pelo isolamento. $\mathrm{O}$ sujeito anômico é aquele que subsiste notadamente à margem das interações sociais, não conseguindo associar-se a nenhum tipo de sistema. Por outro lado, o indivíduo isolado constrói uma interação simbólica com a sociedade segundo a qual os eventos que nela ocorrem são para ele incontroláveis e irremediáveis (GUERREIRO RAMOS, 1981).

A distribuição dos recursos em uma sociedade paraeconômica não mais deverá obedecer a parâmetros exclusivamente econômicos. Da mesma forma, esses mesmos critérios não devem ser os únicos a ser levados em consideração quando da avaliação da qualidade e do desenvolvimento de uma sociedade. Ao contrário, essa avaliação também precisa ser realizada com base na geração de valores intangíveis que ultrapassem um simples processo de troca mercadológica (GUERREIRO RAMOS, 1981). 
Além disso, "o paradigma paraeconômico pressupõe que o desenvolvimento do mercado deva ser politicamente regulado, de modo que não venha a solapar a base dos enclaves isonômicos e fenonômicos" (GUERREIRO RAMOS, 1981, p. 184). O autor deixa bem claro que não se trata de regulação por meio da intervenção de um Estado socialista. Muito ao contrário, a regulação deve surgir pela via da sociedade consciente da necessidade de que somente a adequada articulação dos diversos sistemas sociais conduz ao seu funcionamento equilibrado. Embora a ênfase do autor tenha recaído sobre os sistemas isonômicos e fenonômicos, ele deixa claro que o desenvolvimento do mercado também poderá deteriorar ainda mais o estado de anomia e isolamento dos indivíduos. Ao contrário, o Estado, alinhado com a nova ciência das organizações, deverá ser justamente capaz de assumir o papel central de articulador, a fim de reverter os contextos extremos do paradigma paraeconômico.

Podemos concluir essa parte da discussão dizendo que a nova ciência das organizações preconizada por Guerreiro Ramos (1981) é sustentada pelo deslocamento referencial que se distancia tanto dos pressupostos utilitaristas como dos constructos exclusivamente sociais. O centro de seu pensamento é definitivamente ocupado pela racionalidade substantiva, ainda que reconhecendo a existência do predicado da razão instrumental. Nas palavras do próprio autor: "Toda teoria da organização existente pressupõe uma ciência social da mesma natureza epistemológica. A contrapartida da atual teoria da organização é a ciência social formal. A contrapartida da nova ciência da organização é a ciência social substantiva" (GUERREIRO RAMOS, 1981, p. 45). Em outras palavras, é a razão substantiva que torna os indivíduos capazes de entender a variação inerente de sua condição humana.

\section{A Controvérsia com a Escola de Frankfurt}

Provavelmente, é na controversa divergência com os teóricos da Escola de Frankfurt que a autonomia dos estudos críticos de Alberto Guerreiro Ramos revela-se de maneira mais consistente. Essa discordância é detalhada, de modo bastante cuidadoso, sobretudo no primeiro capítulo da obra A nova ciência das organizações.

Segundo Tenório (2008), um grupo de estudiosos alemães comandados por Felix Weil reuniu-se em 1922 na cidade de Ilmenau, Turíngia, com a finalidade de promover um simpósio de debates sobre o marxismo, por eles denominado Primeira Semana de Trabalho Marxista. No ano seguinte, em 1923, o grupo transferiu-se para o Instituto de Pesquisa Social da Universidade de Frankfurt, que, mais tarde, acabou alcançando notoriedade sob o nome de Escola de Frankfurt.

Entretanto, somente em 1931, com a ascensão de Max Horkheimer à direção do instituto, a Escola de Frankfurt consolidou-se como movimento intelectual, migrando da ortodoxia marxista para uma visão mais ampliada, não mais concentrada apenas nos estudos econômicos. Nesse período, ingressaram na escola pensadores como Theodor W. Adorno, Erich Fromm e Herbert Marcuse (TENÓRIO, 2008).

Em 1933, com a chegada de Adolph Hitler ao poder na Alemanha, o instituto é obrigado a descentralizar suas atividades, criando núcleos na Suíça e na França. Posteriormente, seus integrantes exilaram-se nos Estados Unidos, passando a desenvolver seus estudos na Universidade de Columbia. Em 1950, o instituto retorna a Frankfurt definitivamente, solidificado como escola, agora não mais dedicando-se exclusivamente ao marxismo (TENÓRIO, 2008).

Foi Max Horkheimer que pela primeira vez denominou teoria crítica o conjunto das produções intelectuais frankfurteanas. Seu objetivo era posicionar o pensamento da escola em um campo epistemológico oposto ao pensamento positivista, então dominante em razão da hegemonia das ciências naturais. Fundamentalmente, uma das maiores contribuições da teoria crítica para a teoria organizacional foram os estudos aprofundados sobre a racionalidade instrumental (TENÓRIO, 2008, p. 16):

Os frankfurteanos da primeira geração mant[ê]m o pessimismo de Weber com relação ao predomínio da racionalidade instrumental na sociedade contemporânea. Para essa possível 
reconciliação serão de fundamental importância os estudos de Jürgen Habermas, frankfurteano da segunda geração, que propõe que este "encontro" se dê por meio da razão comunicativa.

Na seção seguinte, teremos a oportunidade de expor nosso entendimento acerca de como a reconciliação mencionada por Tenório (2008) provavelmente se dá por meio da junção entre as racionalidades substantiva, conforme recomenda Guerreiro Ramos e comunicativa idealizada por Jürgen Habermas. Para tanto, primeiramente serão discutidas as ideias de Horkheimer, Marcuse e Adorno e, em seguida, chegaremos ao encontro de Guerreiro Ramos com Habermas.

\section{Horkheimer e a crise da razão}

Para Horkheimer (2007), o modelo de pensamento humano até então hegemônico funcionava de acordo com uma estrutura que conectava em seu interior os meios e os fins como forma de atender a um propósito de utilidade. Dizendo de outra forma, vivemos em uma sociedade na qual uma noção de racionalidade que não associe determinado objetivo a algum tipo de vantagem para o sujeito não será, provavelmente, bem compreendida. Horkheimer (2007) denominou esse tipo de razão, que esvazia o significado do objeto em detrimento da subjetividade, razão subjetiva.

Entretanto, ainda de acordo com o autor, a subjetividade que qualifica esse tipo de racionalidade caracterizase, essencialmente, pelo alinhamento acrítico ao processo mecanicista de socialização. Dessa forma, convertida em conformismo, a subjetividade distorcida, unida à incapacidade de conceber um objetivo com fins per se e independente de ganhos ou proveitos, oferece como resultado a crise, o apagamento ou, simplesmente, o "eclipse" da razão. De forma geral, a adequação humana a esse arquétipo de racionalidade ocorre automaticamente. A concepção de Horkheimer (2007) sobre razão subjetiva, segundo o próprio autor, aproxima-se, muito, do conceito atribuído por Max Weber à razão formal ou funcional.

Para contrapor a racionalidade subjetiva, Horkheimer (2007, p. 17, grifo nosso) define o que denomina razão objetiva:

Assim, por um lado o termo razão objetiva denota como essência uma estrutura inerente à realidade que por si mesma exige um modo específico de comportamento em cada caso, seja uma atitude prática ou seja teórica. Por outro lado, o termo razão objetiva pode também designar o próprio esforço e capacidade de refletir tal ordem objetiva.

Em outras palavras, o que Horkheimer (2007) denomina razão objetiva é a capacidade de compreender as diversas situações em suas particularidades, à parte de interesses subjetivos. Esse tipo de razão, que os iluministas desejavam tomar do catolicismo e da filosofia ocidental a fim de romper com o dogmatismo, acabou sendo liquidada e convertida ao pragmatismo e ao positivismo moderno, provavelmente, outra forma de dogmatismo, apenas transferida dos altares para os laboratórios. Efetivamente, "os filósofos do Iluminismo atacaram a religião em nome da razão; e afinal o que eles mataram não foi a Igreja mas a metafísica e o próprio conceito de razão objetiva" (HORKHEIMER, 2007, p. 23). Por fim, o que se presenciou foi o triunfo inequívoco da subjetividade formal.

Assim, ideias, pensamentos, linguagens, são exauridos de significado e nada que não possa ser avaliado em termos funcionais parece ter direito a fazer sentido na sociedade moderna. Tudo e todos se reduzem a peças, engrenagens que devem acolher sua função mecânica na grande máquina que são as estruturas de produção. O indivíduo submete-se à vontade de terceiros assumindo tal subordinação como um papel social "legítimo" (HORKHEIMER, 2007, p. 26):

Tendo cedido em sua autonomia, a razão tornou-se um instrumento. No aspecto formalista da razão subjetiva, sublinhado pelo positivismo, enfatiza-se a sua não referência a um conteúdo objetivo; em seu aspecto instrumental, sublinhado pelo pragmatismo, enfatiza-se 
a sua submissão a conteúdos heterônimos. A razão tornou-se algo inteiramente aproveitado no processo social. Seu valor operacional, seu papel no domínio dos homens e da natureza tornou-se o único critério para avaliá-la.

Ocorre, de fato, uma inversão. Qualquer atitude tomada com fundamento na razão objetiva, conforme preconizada por Horkheimer (2007), passa a ser entendida como irracionalidade a partir do momento que não se conecta com o conjunto de propósitos da lógica utilitarista. Na sociedade do século XX (e, quem sabe, também na do século XXI), a adesão aos princípios instrumentais parece ser a única alternativa. Os desejos do sistema confundem-se com os desejos das pessoas (HORKHEIMER, 2007). Em outras palavras, "nossa espontaneidade foi substituída por uma disposição de espírito que nos obriga a descartar-nos de qualquer emoção ou ideia que possa diminuir nossa atenção às exigências impessoais que nos assaltam" (HORKHEIMER, 2007, p. 103).

Dessa forma, segundo Horkheimer (2007), todos nós nos tornamos escravos dos substratos iluministas: o positivismo, o pragmatismo, a tecnologia. Entretanto, não se resolve esse problema rompendo-se com a sociedade industrial e retornando aos formatos pregressos de dominação social. Ao contrário, a solução para a crise da razão consiste, de acordo com Horkheimer (2007) na libertação do pensamento independente.

Theodor W. Adorno (2009), cuja filosofia é a mesma de Horkheimer (2007), focaliza o dano à objetividade causado pela quantificação inerente aos métodos científicos fundamentalmente positivistas. Nas palavras de Adorno (2009, p. 45), "a absolutização da tendência de quantificação própria à ratio [razão] coincide com a sua falta de autorreflexão". Dizendo de outra maneira, não significa remover do contexto histórico aquilo que pode e deve ser quantificado. Entretanto, essa quantificação não deve ser um fim em si, devendo resultar dela uma ou mais reflexões qualitativas. Isso se entende por autorreflexão: uma segunda reflexão, de evidência qualitativa, que visa a impedir que a racionalidade converta-se em irracionalidade (ADORNO, 2009, p. 45).

\section{Marcuse e a racionalidade tecnológica}

Aponta Marcuse (1973) que o problema da objetividade histórica constitui, talvez, uma das maiores questões sobre as quais a análise crítica deve debruçar-se. A transformação qualitativa, reclamada por Adorno (2009), é considerada pelo autor extremamente necessária como forma de conter a adesão cada vez maior da sociedade à irracionalidade gerada a partir de seu "racionalismo arrasador" (MARCUSE, 1973, p. 17).

Para Marcuse (1973), a moderna sociedade industrial caracteriza-se por ser unidimensional. Essa unidimensionalidade sustenta-se sobre o permanente conflito entre forças que desejam, ao mesmo tempo, retrair e liberar a transformação qualitativa. Contudo, um fator tem sido preponderante, segundo Marcuse (1973), na prevalência do contexto não transformado. Trata-se da evolução do aparato tecnológico (MARCUSE, 1973).

Sustenta o autor que é por meio da tecnologia que os mecanismos controladores da sociedade ampliam-se de forma a unidimensionalizar, dentro da tessitura social, "as necessidades e aspirações individuais" (MARCUSE, 1973, p. 18), eliminando quase que completamente as possibilidades de escolha. Dessa forma, configura-se uma tendência totalitária cada vez mais acentuada que não mais pode ser dissociada do contexto político (MARCUSE, 1973, p. 19):

No ambiente tecnológico, a cultura, a política e a economia se fundem num sistema onipresente que engolfa ou rejeita todas as alternativas. O potencial de produtividade e crescimento desse sistema estabiliza a sociedade e contém o progresso técnico dentro da estrutura de dominação. A racionalidade tecnológica ter-se-á tornado racionalidade política.

O totalitarismo verificado por Marcuse (1973) na essência da racionalidade tecnológica contribui de forma crescente, no entendimento do autor, para a supressão da autonomia do indivíduo, tornando-o incapaz de identificar as próprias necessidades. A tecnologia, que unifica o acesso de servos e senhores aos mesmos 
meios de informação, cultura e entretenimento serve-se ao propósito ideológico de construir uma estabilidade social controlada pela suposta satisfação de falsos desejos (MARCUSE, 1973).

De acordo ainda com o autor, dentre todas as mutações aplicadas ao conceito de racionalidade, a tecnológica é a mais recente. Segundo Marcuse (1973), a tecnologia hiperdesenvolvida conseguiu elevar ao mais alto nível, aquilo que os recursos instrumentais pré-tecnológicos tanto se esforçaram para conseguir, a legitimidade da dominação de uma "sociedade racionalmente totalitária" (MARCUSE, 1973, p. 154). Em outras palavras, "a tecnologia se tornou o grande veículo de espoliação - espoliação em sua forma mais madura e eficaz” (MARCUSE, 1973, p. 162).

Marcuse (1973) concede centralidade à racionalidade tecnológica no artifício de eliminar o caráter bidimensional, dialético e negativo (no sentido de negar) da Razão (com letra maiúscula, como assinala o autor ao referir-se à verdadeira razão). Conquanto isso não seja possível, a sociedade industrial avançada contenta-se em manter latente o falso equilíbrio entre "a produtividade crescente e seu uso repressivo" (MARCUSE, 1973, p. 234). Nada mais que uma unidimensionalização aparente incapaz de sanar as verdadeiras contradições (MARCUSE, 1973).

\section{Guerreiro Ramos: a crítica da teoria crítica}

De acordo com Guerreiro Ramos (1981, p. 19), o fio condutor que une as ideias dos principais pensadores da Escola de Frankfurt é a crença de que "a racionalidade se transformou numa categoria sociomórfica, isto é, é interpretada como um atributo dos processos históricos e sociais, e não como força ativa na psique humana”. Nesse sentido, ainda que reconheça o valor de seus autores na revisão do pensamento marxista, Guerreiro Ramos (1981) considera que, de certa forma, os escritos frankfurteanos são limitados por desconsiderar em suas obras, na devida magnitude, a importância da substantividade.

Para Guerreiro Ramos (1981), os textos de Horkheimer e Adorno apontam o Iluminismo como momento histórico decisivo no qual a ideia de razão divorcia-se de seu conceito clássico original. A partir daí, os autores acentuam a ascensão do funcionalismo, do formalismo lógico e do mecanicismo perpetrados pelo positivismo científico característico das ciências naturais (GUERREIRO RAMOS, 1981).

O autor ainda salienta a ênfase de Horkheimer na desnaturação da linguagem e sua transformação em instrumento a serviço da lógica produtiva. No nexo instrumental, segundo Horkheimer (1947 apud GUERREIRO RAMOS, 1981, p.10), o homem moderno é descrito como "um ego contraído, prisioneiro de um presente efêmero, esquecendo-se de usar suas funções intelectuais pelas quais foi capaz, um dia, de transcender sua efetiva posição na realidade". Completa Guerreiro Ramos (1981) que esse homem, desintelectualizado e incapaz de transmitir significados, age unicamente em função de propósitos.

Contudo, de acordo com Guerreiro Ramos (1981, p. 19), ao considerar que a racionalidade constitui preponderantemente apenas um construto social, Horkheimer torna obscura a relevância das ciências sociais, transformando sua obra, exclusivamente, em um manifesto de indignação moral, em uma acusação à sociedade moderna, que não oferece alternativas para os "males atuais, teóricos e sociais".

De fato, o incômodo quanto ao sociomorfismo e à pouca importância atribuída à racionalidade substantiva também ocupa posto relevante nos escritos de Marcuse (1973). Conquanto Guerreiro Ramos (1981) não tenha se referido a ele nas críticas que direcionou à Escola de Frankfurt, podemos acrescentar, aqui, uma referência que confirma o que diz o autor brasileiro: "Pode-se desprezar a ideia de uma 'força-motriz' inata na natureza humana. Trata-se de conceito psicológico altamente ambíguo e grosseiramente inadequado para a análise do encadeamento dos acontecimentos sociais" (MARCUSE, 1973, p. 59).

Aquilo que Marcuse (1973) denomina "força-motriz inata na natureza humana" e que, segundo ele, pode ser reduzido a uma inconsistência restrita ao campo da psicologia, na realidade pode ser interpretado como a face substantiva da racionalidade e, em oposição ao que diz o autor, consiste exatamente no sustentáculo da 
proposta formulada por Guerreiro Ramos (1981) em A nova ciência das organizações, já discutida neste artigo.

Como muitos pesquisadores já apontaram, Guerreiro Ramos foi um crítico dos estudos organizacionais convencionais. Por esse motivo, muitas vezes é identificado no quadro da teoria crítica. No entanto, ele mesmo afirma que crítica, por si só, não faz sentido se não houver uma proposta para superar os problemas que identifica. Isso, por um lado, afasta-o dos teóricos críticos convencionais que se limitam à apresentação da crítica. Por outro, aproxima-o de Habermas, que ultrapassa a crítica pela crítica.

\section{A Reconciliação: Guerreiro Ramos e Jürgen Habermas}

Segundo Tenório (2008), a primeira geração da Escola de Frankfurt mantém-se pessimista quanto à manutenção da hegemonia instrumental na atual sociedade. Coube, principalmente, a Jürgen Habermas, teórico crítico de segunda geração, estabelecer uma via de recuperação da racionalidade como solução e não como problema, construindo, assim como Guerreiro Ramos, uma proposta para um novo paradigma de sociedade. No núcleo de sua obra encontra-se a preocupação com a construção de um novo ideal de democracia conciliando elementos como a esfera pública e o agir comunicativo (TENÓRIO, 2008).

\section{A abordagem habermasiana}

A teoria habermasiana do direito expressa-se na reflexão sobre sua legitimidade, por meio da reconstrução do conceito de democracia pela via da comunicação ou da teoria do discurso. A discussão do tema é centrada na tensão entre facticidade, conceito segundo o qual o homem submete-se a algo que não escolheu, e validade, que são os requisitos formais e essenciais sobre os quais se sustentam os atos jurídicos. Tal debate pode tanto ser realizado no núcleo do próprio direito como de forma externa a ele. No segundo caso, a argumentação flui entre a facticidade dos processos políticos e a autocompreensão normativa do Estado de direito (HABERMAS, 2011).

A conclusão de Habermas (2011, p. 18) é que as regras convencionais do jogo democrático nada mais são que uma "teoria filosófica comprometida em justificar as regras da democracia liberal". Em outras palavras, trata-se de um posicionamento ideológico característico do Estado de direito do liberalismo, propagada como única opção viável de regime democrático, o que, naturalmente, não se fundamenta de modo racional.

O que Habermas (2011) propõe é focalizar a democracia deliberativa como elemento central do processo democrático. A perspectiva habermasiana situa-se em uma região intermediária entre os direitos fundamentais liberais e a interpretação republicana. No âmago da instância deliberativa encontra-se a teoria do discurso que absorve da democracia liberal os direitos humanos universais e, do republicanismo, a eticidade concreta. Assim, o conteúdo democrático é extraído pela via do discurso constituindo as bases válidas do agir orientado pelo entendimento (HABERMAS, 2011). Em outras palavras, a democracia deliberativa constrói-se a partir da articulação entre formação de opinião e vontade com os aspectos constitucionais do Estado de direito, sendo essa maneira mais coerente para a "racionalização discursiva das decisões de um governo e de uma administração" (HABERMAS, 2011, p. 23).

Segundo Habermas (2011), a esfera pública consiste em um espaço amplo de participação democrática, estranho à centralização e dominação elitista. Em suas próprias palavras (HABERMAS, 2011, p. 93):

A esfera pública pode ser descrita como uma rede adequada para a comunicação de conteúdos, tomadas de posições e opiniões; nela os fluxos comunicacionais são filtrados e sintetizados, a ponto de se condensarem em opiniões públicas enfeixadas em termos específicos. Do mesmo modo que o mundo da vida tomado globalmente, a esfera pública se reproduz através do agir comunicativo, implicando apenas o domínio de uma linguagem 
natural; ela está em sintonia com a compreensibilidade geral da prática comunicativa cotidiana [...]. A esfera pública constitui principalmente uma estrutura comunicacional do agir orientado pelo entendimento, a qual tem a ver com o espaço social gerado no agir comunicativo, não com funções nem com os conteúdos da comunicação cotidiana.

Dizendo de outra maneira, na essência da esfera pública está a intersubjetividade, que se revela a partir do momento que os sujeitos, não submetidos a qualquer tipo de ação repressiva, alcançam um consenso pela via do melhor argumento. Habermas (2011) almeja revigorar o conceito de esfera pública, a fim de alcançar uma ideal totalidade política da sociedade, por meio de uma reconstrução da cidadania, tornando-a capaz de apropriar-se do poder burocrático estatal e configurando uma nova maneira de autoadministração descentralizada.

A sociedade civil é, hoje, o principal componente canalizador dos problemas sociais que repercutem na esfera privada e são transmitidos para a esfera pública política. É no âmago da sociedade civil que os movimentos sociais e outras organizações agrupam-se para estruturar os discursos orientadores sobre questões de interesse geral (HABERMAS, 2011). Dessa maneira, a sociedade interfere na formação da opinião pública e sensibiliza o sistema político principalmente por meio dos partidos e da atividade eleitoral. Para que a relação entre sociedade e esfera pública seja perene, é preciso que as estruturas comunicacionais desta última permaneçam ilesas (HABERMAS, 2011).

Em outras palavras, a essência da política deliberativa é composta por uma rede de discursos e negociações criadas com a finalidade de obter soluções racionais para temas pragmáticos, morais e éticos, os quais constituem um legado de problemas, resultantes de uma frustrada coleção de fracassos sociais históricos. O agir comunicativo consiste justamente na mediação social por meio da comunicação, concretizada no momento histórico e no espaço social. Habermas (1989, p. 165) fala em:

[...] agir comunicativo quando os atores tratam de harmonizar internamente seus planos de ação e de só perseguir suas respectivas metas sob condição de um acordo existente ou a se negociar sobre a situação e as consequências esperadas [...] o modelo do agir orientado para o entendimento mútuo tem que especificar condições para um acordo alcançado comunicativamente [...] Os processos de entendimento mútuo visam um acordo que depende do assentimento racionalmente motivado ao conteúdo de um proferimento.

Escrevendo de outra forma, é por meio da racionalidade comunicativa que o conjunto cultivado pela formação pública da vontade, pelas disposições institucionalizadas e pelas deliberações legislativas poderão ser capazes de promover a transformação do poder produzido comunicativamente em poder aplicável administrativamente pela via da legislação. Espera-se, como resultado dessa interação, uma sociedade soberana, distanciada tanto do Estado como do sistema econômico.

Em relação a Habermas, Guerreiro Ramos (1981, p. 10) reconhece o mérito do autor ao relevar aspectos importantes da sua obra, principalmente a recuperação dos "padrões éticos" na análise da racionalidade no interior da sociedade moderna. Sobretudo, Guerreiro Ramos (1981) identifica em Habermas a "padronização da comunicação como ponto central de uma teoria social integrativa crítica" (GUERREIRO RAMOS, 1981, p. 11).

Também salienta Guerreiro Ramos (1981, p. 12) que Habermas coloca-se como "continuador da teoria marxista", contudo, "liberada de seus erros". Esse acerto de direção do pensamento marxista consiste, principalmente, em constatar que, ao contrário do que escreveu Marx, a racionalidade, como resultado do desenvolvimento da sociedade industrial, não se converteu em subsídio para a emancipação do homem. Antes, a racionalidade instrumentalizada deteriorou sua subjetividade e criou sérios entraves à sua "genuína comunicação" (GUERREIRO RAMOS, 1981, p. 13). 
Ainda de acordo com Guerreiro Ramos (1981, p. 14), a "tese central de Habermas é a de que, na moderna sociedade industrial, as antigas bases de interação simbólica foram solapadas pelos sistemas de conduta de ação social com propósito". Dizendo de outra maneira, na sociedade moderna, apenas de forma incidental os indivíduos poderão ser capazes de interagir simbolicamente. Essa agressão ao simbolismo, por meio do domínio de fatores políticos que esvaziam os significados dos discursos, resulta na unidimensionalidade da vida humana.

Entretanto, Guerreiro Ramos (1981) considera a obra de Habermas superficial e, mais uma vez, ressalva, assim como fez em relação à obra de Horkheimer, o protagonismo do sociomorfismo em seus escritos. De forma geral, também entende Guerreiro Ramos (1981, p. 20) que, para Habermas, a emancipação humana se dá de forma coletiva, encaminhada por um processo de esclarecimento grupal, ignorando, de certa forma, que esse mesmo esclarecimento não pode desconectar-se "da psique individual".

\section{A racionalidade substantiva em Habermas e a racionalidade comunicativa em Guerreiro Ramos}

Guerreiro Ramos (1981, p. 13), em que pesem os contundentes senões sobre a incipiência dos trabalhos de Habermas acerca da racionalidade, admite sua disposição em aprimorar as ideias sobre o tema:

Habermas considera necessário desenvolver mais a racionalidade, uma vez que a sociedade industrial, em seu atual estágio, é muito diferente daquela que Weber conheceu. Weber podia voltar-se para o tema como um funcionalista, mas hoje a questão acarreta impressionantes conotações éticas, que o esforço teórico de Habermas realça consideravelmente.

Contudo, é muito importante notar que a avaliação da obra de Habermas, feita por Guerreiro Ramos (1981), concentra-se em trabalhos escritos no final da década de 1970. Um exame cuidadoso poderá verificar que o amadurecimento da teoria habermasiana do agir comunicativo somente se dará no início dos anos 1980. Além disso, a ideia de democracia deliberativa, outro ponto da obra de Habermas que aqui relevamos, somente despontará, por completo, aproximadamente dez anos depois.

O que nosso trabalho busca mostrar, nos parágrafos seguintes, é que não existe divórcio efetivo entre as ideias de Guerreiro Ramos e Jürgen Habermas, senão o perpetrado momentaneamente por um lapso temporal. Como argumentamos adiante, as principais obras posteriores de Habermas se encarregarão de demonstrar que as diferenças no pensamento de ambos serão diluídas até o ponto em que se encontram mais complementaridades que divergências.

Sustenta Habermas (2011) que a esfera pública deve preservar a autonomia dos sujeitos, a partir do momento em que estes, ao agir comunicativamente, não esvaziarão suas interpretações, ao contrário, as negociarão cooperativamente com a finalidade de chegar ao entendimento. A partir do momento em que esse agir orientado ao entendimento apoia-se na suposta capacidade humana de tomar decisões autônomas eivadas de caráter moral e ético, entendemos que a razão substantiva está, sim, presente de forma acentuada em Habermas. O que se confirma pelas seguintes palavras:

As associações só podem afirmar sua autonomia e conservar sua espontaneidade na medida em que puderem apoiar-se num pluralismo de formas de vida, subculturas e credos religiosos. A proteção da "privacidade" através de direitos fundamentais serve à incolumidade de domínios vitais privados; direitos da personalidade, liberdades de crença e de consciência, liberalidade [...] caracterizam uma zona inviolável da integridade pessoal e da formação do juizo e da consciência autônoma (HABERMAS, 2011, p. 102, grifo nosso).

Em outras palavras, Habermas (2011) solidariza-se com Guerreiro Ramos (1981) ao introduzir no arcabouço conceitual do agir comunicativo características inseparáveis da psique humana, como personalidade, 
integridade pessoal, juízo e consciência autônoma. Se entendermos que essas características também são atributos da razão substantiva, podemos falar, então, em substantividade da racionalidade comunicativa.

A crítica arraigada de Guerreiro Ramos (1981) à racionalidade instrumental também é ampliada para as raias do aspecto psicológico. Dessa maneira, o autor desenvolve o conceito atordoante de "síndrome comportamentalista". O comportamento, de acordo com Guerreiro Ramos (1981), consiste na absorção, por parte das pessoas, de aspectos normativos exteriores às suas individualidades. Em outras palavras, o indivíduo assume como suas as características do sistema ora impostas dentro de um contexto histórico que as legitima. O resultado da adequação forçada a comportamentos é a naturalização de um relativismo maquiavélico conveniente em detrimento do senso comum humano. Ou seja, a sociedade centrada no mercado tornou fluidas as fronteiras entre o calculismo e a natureza humana propriamente dita (GUERREIRO RAMOS, 1981).

A disseminação da síndrome comportamentalista consubstanciou uma tipologia de análise organizacional behaviorista de onde emerge o conceito de política cognitiva (GUERREIRO RAMOS, 1981). Uma vez que tal política, a partir do âmbito organizacional, presta-se a iludir toda a sociedade, fazendo-a acreditar que não há outra opção a não ser a proliferação do credo mercadológico, nenhuma outra análise psicológica se torna realmente mais conveniente que a behaviorista (GUERREIRO RAMOS, 1981).

Neste ponto da discussão, vale trazer novamente à tona a confrontação com as ideias de Jürgen Habermas. Em meio aos comentários introdutórios sobre a síndrome comportamentalista, afirma o autor brasileiro (GUERREIRO RAMOS, 1981, p. 52, grifo nosso):

O bom homem, por sua vez, nunca é um ser inteiramente socializado; é, antes, um ator sob tensão, cedendo ou resistindo aos estímulos sociais, com base em seu senso ético. Na verdade, os processos não regulados do mercado jamais podem gerar uma boa sociedade. Tal sociedade só pode resultar das deliberações de seus membros em busca da configuração ética, substantiva, de sua vida associada.

Permitimo-nos concluir, portanto, que, ao estabelecer a deliberação como única via capaz de prover a consecução do que Guerreiro Ramos (1981) define como "boa sociedade", o autor aproxima-se fundamentalmente do ideal de democracia deliberativa e da teoria do agir comunicativo, conceitos constantemente enfatizados por Habermas $(1989 ; 2011)$. Acreditando que a racionalidade substantiva está presente nos entremeios de todo o arcabouço conceitual do paradigma paraeconômico e da delimitação dos sistemas sociais, interpretamos essa citação de Guerreiro Ramos (1981) como uma provável adesão a um pressuposto comunicativo. Em outras palavras, seria a comunicatividade da racionalidade substantiva.

\section{Considerações Finais}

Tentamos, ao longo deste artigo, reconstruir de modo paulatino e, obviamente, de forma concisa, a trajetória intelectual de Alberto Guerreiro Ramos. Nossa intenção era, em um primeiro momento, mostrar ao leitor a consistência de sua obra e alicerçar as bases das quais, posteriormente, extrairíamos os subsídios que serviriam à nossa discussão principal, qual seja, assegurar sua autonomia crítica perante os pensadores da Escola de Frankfurt. Daí a necessidade de discorrer sobre as contribuições epistemológicas que consideramos fundamentais na bibliografia do autor.

Isso feito, foi necessário, em um segundo momento, conferir também centralidade aos escritos dos principais autores da referida escola. Nessa etapa, procuramos identificar os aspectos mais relevantes acerca do debate sobre racionalidade. A ideia era expor tais conceitos à parte do que Guerreiro Ramos escreveu sobre eles e, posteriormente, confrontá-los com as noções do autor. 
Encontramos, como resultado, convergências e divergências que conduziram os autores a ênfases diferentes, em conformidade com o contexto no qual escreveram e com as discussões pregressas que tiveram a oportunidade de analisar. Dessa forma, diferentes visões de racionalidade foram abordadas, como a racionalidade formal (Weber), a racionalidade subjetiva (Horkheimer e Adorno) e a racionalidade tecnológica (Marcuse). Todas estas, de uma forma ou de outra, focam-se em uma ideia mais abrangente de racionalidade instrumental, mencionada também por Guerreiro Ramos (1981), e que pode incluir outras expressões presentes na literatura, embora não esclarecidas neste artigo, como racionalidade legal, econômica, funcional, técnica ou científica. Trata-se do tipo de racionalidade difundida pela sociedade moderna industrial que se caracteriza, principalmente, pelo utilitarismo, pela impessoalidade, pelo mecanicismo, pela cientificidade, enfim, pela reificação do homem.

Em oposição, também foram discutidas as racionalidades objetiva (Horkheimer e Adorno), comunicativa (Habermas) e, fundamentalmente, substantiva (Guerreiro Ramos). Para estas, como mostramos, concedem-se atributos éticos, morais, pessoais, de alguma forma associados à psique humana. Ou, como muito bem escrevem Fernandes e Ponchirolli (2011, p. 624): "enquanto numa racionalidade instrumental o que está em jogo como critério de tomada de decisão e como motivação são a eficácia, o rendimento e o desempenho, na racionalidade substantiva são as obrigações éticas e morais".

Para Guerreiro Ramos e Habermas, a alteração dos paradigmas da sociedade moderna passa, necessariamente, pelo caminho de um deslocamento referencial: da racionalidade instrumental para a racionalidade substantiva e comunicativa, se nos for permitido escrever dessa forma. O que supostamente denominamos racionalidade substantiva e comunicativa corresponde às convergências que encontramos nos pensamentos de Alberto Guerreiro Ramos e Jürgen Habermas. Como descrevemos, os estudos de Habermas escritos depois da última obra de Guerreiro Ramos, A nova ciência das organizações, direcionaram-se a um ponto um pouco mais distante da visão quase exclusivamente sociomórfica dos frankfurteanos de primeira geração, ficando bem mais próxima de uma abordagem mais substantiva. Procuramos, assim, ponderar sobre o problema da racionalidade sob uma nova perspectiva que aproximasse duas construções intelectuais: o caráter individual da racionalidade substantiva e a essência coletiva da racionalidade comunicativa.

Cabe ressaltar, como lembra Guerreiro Ramos (1981, p. 191), que a sociedade industrial se originou não menos "como uma possibilidade objetiva", no mesmo sentido de objetividade compreendida por Horkheimer (2007). Sua instrumentalização consubstanciou-se ao longo de "todo um processo acumulativo de inovação institucional, deliberadamente empreendido por muitos indivíduos" (GUERREIRO RAMOS, 1981, p. 191).

Para reverter o atual contexto, assumindo as propostas de Guerreiro Ramos e Jürgen Habermas como esboços concretos de uma nova sociedade, basta agora que se inicie um novo processo de "institucionalização, de que pode emergir uma alternativa para a sociedade centrada no mercado - a sociedade multicêntrica ou reticular" (GUERREIRO RAMOS, 1981, p. 191). Essa institucionalização terá de encontrar lugar para uma fortalecida esfera pública, para um legítimo agir comunicativo e para uma efetiva democracia deliberativa.

\section{Referências}

ADORNO, T. W. Dialética negativa. Rio de Janeiro: Zahar, 2009.

ARISTÓTELES. Ética a Nicômaco. São Paulo: Martin Claret, 2001.

BRIGAGÃO, C. Da sociologia em mangas de camisa à túnica inconsútil do saber. In: GUERREIRO RAMOS, A. Introdução crítica à sociologia brasileira. Rio de Janeiro: Ed. UFRJ, 1995. 8-18 p.

FARIA, J. H. Consciência crítica com ciência idealista: paradoxos da redução sociológica na fenomenologia de Guerreiro Ramos. Cad. EBAPE.BR, v. 7, n. 3, p. 419-446, 2009. 
FERNANDES, V.; PONCHIROLLI, O. Contribuições da racionalidade comunicativa, racionalidade substantiva e ambiental para os estudos organizacionais. Cad. EBAPE.BR, v. 9, n. Edição especial, p. 604-626, 2011.

GUERREIRO RAMOS, A. A sociologia de Max Weber (sua importância para a teoria e a prática da Administração). RSP, v. 3, n. 2-3, p. 267-282, 1946.

GUERREIRO RAMOS, A. A redução sociológica. Rio de Janeiro: Tempo Brasileiro, 1965.

GUERREIRO RAMOS, A. A nova ciência das organizações: uma reconceituação da riqueza das nações. Rio de Janeiro: Ed. FGV, 1981.

GUERREIRO RAMOS, A. Administração e contexto brasileiro. Rio de Janeiro: Ed. FGV, 1983.

GUERREIRO RAMOS, A. Introdução crítica à sociologia brasileira. Rio de Janeiro: Ed. UFRJ, 1995.

GUERREIRO RAMOS, A. A modernização em nova perspectiva: em busca do modelo da possibilidade. In: HEIDEMANN, F. G.; SALM, J. F. (Org.). Políticas públicas e desenvolvimento: bases epistemológicas e modelos de análise. Brasília, DF: Ed. UnB, 2009. 41-79 p.

HABERMAS, J. Consciência moral e agir comunicativo. Rio de Janeiro: Tempo Brasileiro, 1989.

HABERMAS, J. Direito e democracia: entre a facticidade e validade. Rio de Janeiro: Tempo Brasileiro, 2011. v. 2.

HORKHEIMER, M. Eclipse da razão. São Paulo: Centauro, 2007.

MANNHEIM, K. Ideologia e utopia. Rio de Janeiro: Zahar, 1968.

MARCUSE, H. A ideologia da sociedade industrial: o homem unidimensional. Rio de Janeiro: Zahar, 1973.

PAES DE PAULA, A. P. et al. A tradição e a autonomia dos estudos organizacionais críticos no Brasil. Revista de Administração de Empresas, v. 50, n. 1, p. 10-23, 2010.

POLANYI, K. A grande transformação. Rio de Janeiro: Campus, 2000.

SERVA, M. A racionalidade substantiva demonstrada na prática administrativa. Revista de Administração de Empresas, v. 37, n. 2, p. 18-30, 1997.

TENÓRIO, F. G. Tem razão a administração? Ijuí, RS: Ed. Unijuí, 2008.

TRAGTENBERG, M. Burocracia e ideologia. São Paulo: Ed. Unesp, 2006.

WEBER, M. A ética protestante e o espírito do capitalismo. São Paulo: Martin Claret, 2001.

ZWICK, E. et al. Administração pública tupiniquim: reflexões a partir da Teoria N e da Teoria P de Guerreiro Ramos.

Cad. EBAPE.BR, v. 10, n. 2, p. 284-301, 2012. 